\title{
The effect of preoperative apple juice on gastric contents, thirst, and
hunger in children
}

William M. Splinter BSC MD FRCPC, James A. Stewart B SC MD FRCPC, John G. Muir MB CH B FFARCS
The effect of $3 \mathrm{ml} \cdot \mathrm{kg}^{-1}$ of apple juice given $2.6 \pm 0.4$ hours preoperatively was investigated in 80 healthy children of ages five to ten years in this prospective, randomized, single blind study. The children who drank apple juice preoperatively had decreased gastric volume, thirst, and hunger $(p<0.05)$. The gastric volume in the control group was $0.43 \pm 0.46 \mathrm{ml} \cdot \mathrm{kg}^{-1}$ and in the patients who received apple juice the gastric volume was $0.24 \pm 0.3 \mathrm{~J} \mathrm{ml} \cdot \mathrm{kg}^{-1}$. The gastric $\mathrm{pH}$ was not significantly different, with the control group's gastric $p H$ being $1.7 \pm 0.6$ and the treated group's $p H$ was $2.2 \pm 1.2$. Further studies of the effects of different volumes and timing of preoperative clear fluids are indicated in paediatric patients.

The appropriate length of time to withhold solid food and clear fluids in children before surgery is unknown. Children fast for variable periods of time, often according to local custom rather than on scientific principles. The purpose of this fast is to minimize the volume of gastric contents. ${ }^{1}$ Children are notorious for breaking their fast prior to surgery. This can create havoc in a busy operating room schedule because of delays and may lead to conflicts between patient, family, surgeon and anaesthetist.

Prolonged fasting does not decrease gastric volume. ${ }^{2} \mathrm{~A}$ short fast after solid food increases gastric volume, ${ }^{3}$ but a

\section{Key words}

ANAESTHESIA: paediatric; COMPLICATIONS: aspiration, prophylaxis; FLUIDS, ORAL: preoperative; GASTROINTESTINAL TRACT: gastric $\mathrm{pH}$, gastric volume, gastric emptying, preoperative fluids.

From the Department of Anaesthesia, Izaak Walton Killam Hospital for Children, Dalhousie University, Halifax, Nova Scotia.

Address correspondence fo: Dr. W. Splinter, Department of Anaesthesia, Children's Hospital of Eastern Ontario, 401 Smyth Rd, Ottawa, Ontario, KIH 8LI. small drink of clear fluid (water) two to three hours preoperatively decreases gastric volume. ${ }^{4}$ This investigation examined the effects of a small drink $\left(3 \mathrm{ml} \cdot \mathrm{kg}^{-1}\right.$ of clear fluid (apple juice) 2.5 hours prior to anaesthesia on gastric contents, thirst, and hunger.

\section{Methods}

The study was approved by the Hospital Ethics Committee and informed written parental consent was obtained. Eighty children ages five to ten years, ASA physical status 1 or 2 , scheduled for elective surgery were randomly assigned to one of two groups. Patients were excluded from the study if (1) there was a history of gastrointestinal disease or (2) the patient was on medication known to affect gastric contents. All children were ordered to fast from midnight. Group $1(n=40)$ continued to fast but in Group 2 the children drank $3 \mathrm{ml} \cdot \mathrm{kg}^{-1}$ of clear apple juice ( $\mathrm{pH}$ approximately 4.5 ) 2.5 hours preoperatively. Immediately prior to anaesthesia both child and parent answered a questionnaire on hunger and thirst, using a linear analogue scale from 1 to 10 . The child graded its degree of thirst from "not thirsty" to "REALLY thirsty" and the parent assessed it from "no thirst at all" to "asking for a drink constantly." Similar grading was used for hunger. Three children, all age five years, were unable to answer the questionnaire.

The patients were not premedicated and all had a routine anaesthetic induction (inhalation of halothane and nitrous oxide or intravenously with sodium pentothal). Tracheal intubation was performed only when indicated. After induction of anaesthesia a 16 Fr. Salem gastric tube was passed either orally or nasally into the stomach by the same investigator who was unaware of the group to which the patient belonged. The position of the gastric tube within the stomach was confirmed by auscultation. Stomach contents were repeatedly aspirated with the gastric tube in several positions and the patient tilted to the right, left, head down and head up positions. The volume of gastric contents was measured by syringe and the $\mathrm{pH}$ by using $\mathrm{pH}$ paper (Merck $\mathrm{pH} 0-14$ and $\mathrm{pH} \mathrm{0-2.5).}$ 
TABLE I Patient and gastric content characteristics

\begin{tabular}{lllllll}
\hline & Age & Weight & $\begin{array}{l}\text { Durationt } \\
\text { of fast } \\
\text { (hours) }\end{array}$ & $\begin{array}{l}\text { Gastric } \\
\mathrm{pH}\end{array}$ & $\begin{array}{l}\text { Volume } \\
\mathrm{ml} \cdot \mathrm{kg}^{-1}\end{array}$ \\
\hline $\begin{array}{c}\text { Group } \\
\text { (years) } \\
\text { mean } \pm \text { SD } \\
\text { range }\end{array}$ & 40 & $7.4 \pm 1.7$ & $26.1 \pm 7.6$ & $14.5 \pm 1.8$ & $\begin{array}{l}1.7 \pm 0.6 \\
1.2-4.5\end{array}$ & $\begin{array}{l}0.43 \pm 0.46 \\
0.01-1.65\end{array}$ \\
$\begin{array}{c}\text { Apple juice } \\
\text { mean } \pm \text { SD } \\
\text { range }\end{array}$ & 40 & $7.5 \pm 1.8$ & $25.4 \pm 9.1$ & $14.5 \pm 2.5$ & $2.2 \pm 1.2$ & $0.24 \pm 0.31^{*}$ \\
\hline
\end{tabular}

†lgnoring treatment with apple juice.

$* p<0.05$

Comparisons between Groups were made using an unpaired Student's t test for parametric data (e.g. , weight, age) while Mann-Whitney-U tests were performed for non-parametric data (e.g., sex, gastric $\mathrm{pH}$, and gastric yolume). The difference between the Groups' risk factors for pulmonary acid-aspiration syndrome was assessed by Chi-square analysis or Fisher's exact test. The potential relationship between either $\mathrm{pH}$ or gastric volume and sex, age, weight and length of fast was evaluated by linear regression analysis. All values are listed as mean \pm standard deviation and were considered statistically significant if $\mathrm{p}<0.05$.

\section{Results}

There were no significant differences between the Groups' sex, age, duration of fast (ignoring treatment with apple juice) or ASA physical status (Table I). Patients who received apple juice had a decreased gastric volume, may have had a reduced risk of severe pulmonary acidaspiration syndrome if regurgitation and aspiration were to occur, were not as hungry as controls (as assessed by child and parent) and were not as thirsty as controls (as assessed by the parent) (Tables I, II and III). The children in Group 2 drank their apple juice $2.6 \pm 0.4$ hours preoperatively. The difference between the Groups' mean $\mathrm{pH}$ was not statistically significant $(\mathrm{p}=0.15$, MannWhitney-U test). By linear regression analysis neither gastric volume nor $\mathrm{pH}$ varied with weight, sex, age or length of fast.

\section{Discussion}

A high percentage of paediatric patients who come to the operating room have a gastric volume $>0.4 \mathrm{ml} \mathrm{kg}^{-1}$ and gastric $\mathrm{pH}<2.5^{5-9}$ Gastric $\mathrm{pH}$ can be significantly increased by the non-particulate antacid sodium citrate, or by the histamine- 2 receptor blockers cimetidine ${ }^{6}$ or

TABLE II Per cent of patients with risk factors for pulmonary acid-aspiration syndrome

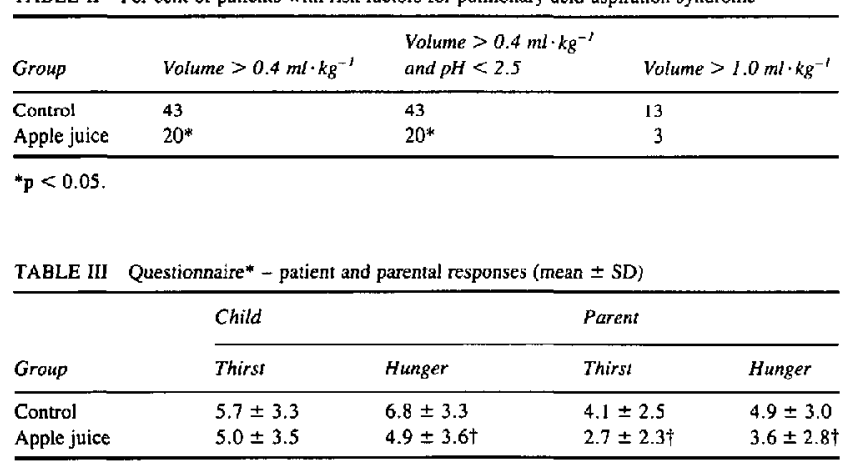

"See Methods for a description of the questionnairc. tp $<0.05$. 
ranitidine. ${ }^{7,10}$ These pharmacologic measures are not without risk as sodium citrate tends to increase gastric volume ${ }^{5}$ and $\mathrm{H}_{2}$ antagonists have known potential adverse reactions. ${ }^{6,9}$ A simple approach, such as optimising the duration of fast prior to surgery, may reduce the potential toxicity of gastric contents and also make the wait for surgery less stressful.

Gastric contents are a function of secretions, ingestion (food, water and saliva) and gastric emptying. Salivary secretions (approximately $1 \mathrm{ml} \cdot \mathrm{kg}^{-1} \cdot \mathrm{hr}^{-1}$ ) ${ }^{11}$ and gastric secretions (approximately $0.6 \mathrm{ml} \cdot \mathrm{kg}^{-1} \cdot \mathrm{hr}^{-1}$ ) ${ }^{11}$ influence fasting gastric volume and $\mathrm{pH}$. Solid foods reduce gastric emptying, ${ }^{12}$ yet clear fluids increase gastric emptying. ${ }^{13}$ Clear fluids have very rapid gastric emptying rates ${ }^{13}$ because they offer minimal resistance at the pylorus and because of their effect on gastric emptying. The effect of a specific clear fluid on the rate of gastric emptying varies with its chemical composition. ${ }^{14}$ This investigation reviewed the effect of apple juice because it is a clear fluid, it is available in most hospitals and homes, most children like it and it has nutritional benefits in addition to caloric content from sugar.

The technique used to measure the volume of gastric contents is a valid and accepted method. ${ }^{15}$ The alternative to direct gastric aspiration is the complicated and timeconsuming dye-dilution technique. ${ }^{15}$

A small drink of apple juice decreased gastric volume. Why did apple juice decrease stomach contents? The increased gastric emptying rate associated with decreased gastric acidity and clear fluid ingestion may have contributed to decreased gastric volume.

The results of the questionnaire suggest a small drink of apple juice decreases the incidence of hunger and thirst in this age group. Unfortunately the answers to the questions are purely subjective and may have been biased by the circumstances of the trial and preoperative interview.

This study involved healthy five- to ten-year-old patients who were not at increased risk of having abnormal gastric contents due to disease, drugs or acute injury. The effect of unrestricted, preoperative, clear fluids on gastric contents, thirst and hunger are unknown. The patients in this trial were given apple juice when they were already in a fasting state and their gastric emptying of clear fluids would not be adversely affected by residual gastric contents, such as solid food. The treated patients benefited from $3 \mathrm{ml} \cdot \mathrm{kg}^{-1}$ of apple juice 2.5 hours preoperatively, in that gastric volume, thirst and hunger were reduced. It is unknown whether larger or smaller volumes would have greater or lesser effect, nor is the best time to start the preoperative fast apparent. Further trials to elucidate these points are in progress

\section{Acknowledgements}

The authors would like to thank their anaesthesia colleagues, surgeons, and nurses for their cooperation; Dr. James Morrison and Dr. Jose Rosales for advice; and Dr. Barry Garner for assistance with statistical analysis

\section{References}

] Hardy $\boldsymbol{J}-\boldsymbol{F}$. Large volume gastroesophageal reflux: a rationale for risk reduction in the perioperative period. Can J Anaesth 1988; 35: 162-73

2 Sutherland $A D$. Stock JG. Davies $J M$. Effects of preoperative fasting on morbidity and gastric contents in patients undergoing day-stay surgery. Br J Anaesth 1986; 58 : 876-8.

3 Meakin G, Dingwall AE, Addison GM. Effects of fasting and oral premedication on the $\mathrm{pH}$ and volume of gastric aspirate in children. Br J Anaesth 1987; 59: 678-82.

4 Sutherland $A D$, Maltby $J R$, Sale $J P$, Reid CRG. The effect of preoperative oral fluid and ranitidine on gastric fluid volume and pH. Can J Anaesth 1987; 34: 117-21.

5 Henderson JH, Spence DG, Clarke WN, Bonn GG, Noel LP. Sodium citrate in paediatric patients. Can J Anaesth 1987; 34: 560-2.

6 Goudsouzian NG, Coté CJ, Liu LMP, Dedrick DF. The dose-response effects of oral cimetidine on gastric $\mathrm{pH}$ and volume in children. Anesthesiology 1981; 55; 533-6.

7 Goudsouzion NG, Young ET. The efficacy of ranitidine in children. Acta Anaesthesiol Scand 1987; 31: 387-90.

8 James CF, Modell JH, Gibbs CP, Kuck EJ, Ruiz BC. Pulmonary aspiration - effects of volume and $\mathrm{pH}$ in the rat. Anesth Analg 1984; 63: 665-8.

9 Goudsouzian NG. Aspiration in children: practical implications. Anesthesiology Review 1984; 11 : 6-16.

I0 Maltby JR, Reid CRG, Hutchinson A. Gastric fluid volume and $\mathrm{pH}$ in elective inpatients. Part II: coffee or orange juice with ranitidine. Can J Anaesth 1988; 35: 16-9.

11 Nordgren $B$. The rate of secretion and electrolyte content of normal gastric juice. Acta Physiol Scand 1963; 58 Suppl p 202.

12 Sleisenger $M H$, Fordiran JS. Gastrointestinal Disease. 3rd ed. Toronto: W. B. Saunders Company, 1983: p 160.

13 Sleisenger MH, Fordtran JS. Gastrointestinal Disease. 3rd ed. Toronto: W. B. Saunders Company, 1983: p 758.

14 Hardy J-F, Plourde G, Lebrun M, Côté C, Dubé S, Lepage $Y$. Determining gastric contents during general anaesthesia: evaluation of two methods. Can J Anaesth 1987; 34 : 474-7.

15 Moare JG, Christian PE, Coleman RE, Gastric emptying of varying meal weight and composition in man. Evaluation by dual liquid- and solid-phase isotopic method. Dig Dis Sci 1981; 26: 16-22. 


\section{Résumé}

Nous avons entrepris une étude prospective, randomisée et à l'aveugle pour déterminer l' effet de $3 \mathrm{ml} \cdot \mathrm{kg}^{-1}$ de jus de pomme donné $2.6 \pm 0.4$ h. avant l'opération à 80 enfants agés de 5 à 10 ans. Les enfants qui avaient bu du jus avant l'opération avaient moins faim et soif et leurs volumes gastriques étaient moindres $(p<0.05)$. Le volume gastrique était de $0.43 \pm 0.46 \mathrm{ml} \cdot \mathrm{kg}^{-1}$ chez le groupe controle, et de $0.24 \pm 0.31 \mathrm{ml} \cdot \mathrm{kg}^{-1}$ chez le groupe "jus de pomm". LepH du liquide se chiffrait à $1.7 \pm 0.6$ pour les contróles et à $2.2 \pm 1.2$ pour les buveurs de jus, écart non significatif. On aura besoin d'autres études pour préciser limpact du volume et de l'intervalle d'administration des liquides clairs chez les enfants. 